\title{
O CASO BERNARDO NO TELEJORNALISMO: A PERCEPÇÃO DE ADVOGADOS SOBRE A APRESENTAÇÃO DO FATO NO JORNAL NA- CIONAL
}

\author{
NATALIA REDÜ \\ UNIVERSIDADE FEDERAL DE PELOTAS \\ PELOTAS, RIO GRANDE DO SUL, BRASIL \\ E-MAIL: NATALIAREDU@GMAIL.COM \\ MICHELE NEGRINI \\ UNIVERSIDADE FEDERAL DE PELOTAS \\ PELOTAS, RIO GRANDE DO SUL, BRASIL \\ E-MAIL: MMNEGRINI@YAHOO.COM.BR
}

HTTP://DX.DOI.ORG/10.5902/2316882X21695 
O CASO BERNARDO NO TELEJORNALISMO: A PERCEPÇÃO DE ADVOGADOS SOBRE A APRESENTAÇÃO DO FATO NO JORNAL NACIONAL

Resumo: Analisar como um determinado grupo de advogados recepciona a morte e as notícias sobre o Caso Bernardo veiculadas no Jornal Nacional. Realizou-se um estudo de recepção com cinco profissionais da área do Direito, através da aplicação de um questionário semiestruturado e de um grupo de discussão. A base teórico-metodológica foram os Estudos Culturais Latino-Americanos, de Martín-Barbero (2013).

Palavras-Chaves: morte; recepção midiática; caso Bernardo; Jornal Nacional.

\section{EL CASO BERNARDO EN EL TELEPERIODISMO: LA PERCEPCIÓN DE ABOGADOS SOBRE LA PRESENTACIÓN DE LA NOTICIA EN EL JOR- NAL NACIONAL}

Resumen: Analizar como un determinado grupo de abogados han recepcionado la muerte y las noticias sobre el Caso Bernardo vehiculadas en el Jornal Nacional. Se realizó un estudio de recepción con cinco profesionales del área del Derecho, através de la aplicación de un cuestionario semiestructurado y de un grupo de discusión. La base teórico-metodológica fueron los Estudios Culturales Latinoamericanos, de Martín-Barbero (2013). Palabras clave: muerte; recepción mediática; caso Bernardo; Jornal Nacional.

BERNARDO'S CASE ON TELEVISION JOURNALISM: THE LAWYER'S PERCEPTION ON THE FACTS PRESENTATION ON JORNAL NACIONAL

Abstract: To analyze how a certain group of lawyers welcome death and the news about Bernardo's Case presented in the Jornal Nacional. A reception study was conducted with five lawyers, through the application of a semi-structured questionnaire and a group discussion. The theoretical-methodological basis was the Latin American Cultural Studies, by Martín-Barbero (2013).

Keywords: death; media reception; Bernardo's Case; Jornal Nacional. 


\section{INTRODUÇÃO}

Uma das recentes e violentas situações de morte retratadas no telejornalismo brasileiro, inclusive pelo Jornal Nacional, diz respeito ao Caso Bernardo. As primeiras notícias sobre o acontecido davam conta de uma situação de desaparecimento do menor. Porém, com o andamento das investigações, verificou-se cenário de morte violenta, cujos principais suspeitos eram o pai e a madrasta do garoto. A partir de então, o fato não ficou restrito às manchetes locais, atingindo âmbito nacional. Diante disso, a proposta deste estudo é analisar a forma como um grupo de advogados recepciona a morte no seu cotidiano, bem como verificar como o público entende as características da morte enfatizadas na cobertura do Jornal Nacional ao Caso Bernardo. Isso porque as crenças, a cultura, a religião de cada um, aliadas à forma e a intensidade da sua transmissão televisiva implicam em conclusões diferentes. Corrobora esta ideia a lição de Barp (2012, p. 05) ao apontar que: "a formação da cultura, bem como da opinião pública, possui uma raiz fixada no conteúdo televisivo".

Ao final do estudo, visa-se verificar se as reportagens veiculadas no Jornal Nacional a respeito do Caso Bernardo foram, de certa forma, tendenciosas ou não. Ou seja, se as reportagens já entregaram ao telespectador uma conclusão pronta e definitiva de que os suspeitos eram os verdadeiros culpados, antes mesmo do fim das investigações e do julgamento.

Como já mencionado, a amostra é composta por um grupo de 5 advogados. No entanto, cumpre destacar que o presente artigo é um recorte de um Trabalho de Conclusão de Curso, no qual a amostra total era composta por 5 advogados e 5 jornalistas, totalizando 10 pessoas. No somatório, o grupo era suficiente para se obter uma análise de recepção científica. Isso porque, conforme ensina Orozco-Gómes (1996), é suficiente que as pesquisas sejam realizadas com um número entre 10 a 20 participantes, uma vez que o aumento no número de pesquisados vai gerar uma diferença insignificante no resultado geral, eis que as respostas aos questionamentos tendem a se repetir. O estudo foi conduzido através da aplicação de um questionário semiestruturado e, após, de uma discussão em grupo a respeito da temática estudada.

O corpus do presente trabalho é composto por duas notícias a respeito do Caso Bernardo veiculadas pelo Jornal Nacional. As notícias sobre o caso começaram a ser inseridas no informativo noturno tão logo a dele

Rev.Cad. Comun. Santa Maria, v.21, n.1, art 6, p.127 de 145, jan/abr.2017 
gada responsável pelas investigações decidiu indiciar o pai, a madrasta e uma amiga da madrasta pela morte do menino.

O Jornal Nacional, no ar desde $1^{\circ}$ de setembro de 1969, é veiculado pela Rede Globo e é um dos principais telejornais do país. A estreia desse informativo foi um marco não só na história da emissora, mas também na história de televisão e do telejornalismo. O incessante investimento em tecnologia e a busca constante na manutenção da audiência fizeram da TV Globo a maior emissora do país. Além disso, ganhou reconhecimento internacional e se tornou fonte de referência para outras emissoras'.

O noticioso, que é o "programa mais antigo em exibição na televisão brasileira" (GOMES, 2010, p. 05), diante de todo investimento feito, conquistou audiência, respeito e credibilidade perante os espectadores. "Não é por acaso que, se algo acontece em qualquer cidade do Brasil, é na Globo que os brasileiros se informam em primeiro lugar" (MEMÓRIA GLOBO, 2004, p. 12). E, dentre os informativos da rede Globo, o de maior relevância entre a população é justamente o Jornal Nacional. Corrobora com esta ideia a afirmação de Maia (2007, p. 23) de que “(...) o Jornal Nacional ainda é um dos programas mais assistidos da televisão brasileira, segundo o lbope".

A cobertura no Jornal Nacional, assim como nas demais mídias, foi intensa. No período de abril de 2014 até abril de 2015, o Jornal Nacional veiculou 18 reportagens sobre o acompanhamento do acontecido. Dentre essas, selecionamos $2^{2}$ para ancorar o presente estudo de recepção: optou-se pelo primeiro da sequência, que foi quando o caso tomou proporções nacionais, e pelo que noticia a conclusão do inquérito policial. Tendo em vista os objetivos do estudo, não foi selecionada nenhuma notícia que já tratava da etapa de julgamento.

1 Fonte: Portal Imprensa. Disponível em: http://portalimprensa.com.br/tv6oanos/ anos60_65_04_26_inauguracao_tv_\%20globo_ri_texto.asp, acesso em 20 de outubro de 2015.

2 Os vídeos selecionados tinham as seguintes manchetes: "Pai, madrasta e uma amiga devem ser indiciados pela morte de menino no RS", exibido em 17 de abril de 2014, disponível em: <http://globoplay.globo.com/v/3289209/>, acesso em 16 de novembro de 2015; e "Pai, madrasta e uma amiga do casal são indiciados no assassinato do menino Bernardo", exibido em 13 de maio de 2014, disponível em: <http://globoplay. globo.com/v/334406o/>, acesso em 16 de novembro de 2015.

Rev.Cad. Comun. Santa Maria, v.21, n.1, art 6, p.128 de 145, jan/abr.2017 


\title{
2 A MORTE NO TELEJORNALISMO
}

A forma e os rituais de enfrentamento da morte se modificaram substancialmente com o passar dos anos. Atualmente, é possível constatar que o luto e as cerimônias de despedidas para os mortos estão cada vez mais diminutos. Ao mesmo tempo, em contradição ao que mostra o cotidiano social, as mortes apresentadas pela mídia têm recebido cada vez mais destaque. Corrobora com este entendimento a lição de Rodrigues (1983, p. 229), ao afirmar que:

\begin{abstract}
Não obstante nossa argumentação, tudo o que estamos dizendo poderia ser aparentemente contestado se ligássemos um aparelho de televisão. Este simples gesto poderia, à primeira vista, demolir todas as acusações de ocultação e negação da morte, dirigidas contra nossa cultura. Um gesto tão simples, que talvez tenha esta função de demolição como um dos seus deveres ocultos: como afirmar que existe todo um esforço social para escondê-la, como sustentar que só pode ser descrita através de eufemismos, como declarar que a educação das nossas crianças ignora a realidade da morte, como dizer que nossa sociedade quer expulsá-la, se os nossos jornais relatam e dissecam dezenas de mortes diariamente, se ela exerce fascínio e é ambicionada mercadoria jornalística [...].
\end{abstract}

A justificativa para tanto pode ser encontrada através da análise dos denominados valores-notícia. A respeito deste assunto, é de suma importância mencionar doutrina de Erbolato (2008). O autor explica que o jornalista faz uso de elementos como proeminência, proximidade, raridade, humor, culto de heróis, expectativa, entre outros, ao decidir quais acontecimentos da vida serão transformados em notícias jornalísticas. Destes valores, é possível identificar no Caso Bernardo: proeminência dos envolvidos (o pai do menor, suspeito do crime, é médico conhecido e respeitado na cidade de Três Passos e oriundo de família abastada), raridade (é situação incomum ver um pai e uma madrasta querer se livrar do filho), expectativa (há anseio em esclarecer os fatos e verificar se os suspeitos realmente cometeram o crime, busca por justiça social).

Além destes aspectos técnicos, devem ser acrescidas outras justificativas, como a globalização e o fortalecimento do capitalismo, as quais são responsáveis pela sociedade capitalista na qual vivemos. Neste contexto, se insere o ensinamento de Guy Debord sobre "Sociedade do Espetá-

Rev.Cad. Comun. Santa Maria, v.21, n.1, art 6, p.129 de 145, jan/abr.2017 
culo"'. Para esta tese, o fator primordial de uma notícia é gerar lucro, ainda que para isso seja necessário manipular ou espetacularizar os acontecimentos.

Em virtude disso, Lisita (2009) considera que, no telejornalismo contemporâneo, as informações que tratam sobre a morte são superficiais e construídas sem provas concretas e sem reflexão adequada e profunda.

Como referido acima, as mortes transmitidas pela mídia se contrapõem às mortes cotidianas porque tudo que não se admite na "morte comum" 'é destacado, reforçado e buscado pela morte midiática: é permitido um longo ritual de despedida do falecido, fatos que remetem à memória do morto são relembrados exaustivamente, o choro e a comoção são aceitos, o culto à trajetória do morto é um recurso largamente utilizado, enfim, o excesso de drama e a exploração das emoções e sentimentos são bem-vindos nas coberturas noticiosas Deste modo, é possível mencionar a conclusão de Barbosa (2004, p.02 e 03) ao dizer que nos informes televisivos "o que importa é o cortejo, as cenas de despedida, com lenços brancos sendo acenados, o choro convulsivo, o olhar de tristeza e a caminhada. (... ) é necessário dar à morte caráter dramático e excessivo".

Outra característica que merece ser destacada é o distanciamento com que o ser humano enfrenta a morte. Isso porque o indivíduo analisa a morte considerando que há um espaço entre ele e a morte já que, não raro, a tragédia ocorre com pessoa que não faz parte das suas relações diárias e mais próximas. Com isso "(... o o homem passa a se ocupar cada vez mais com a morte do outro, esquecendo-se da sua própria morte". (BARBOSA, 2004, p. 11).

Por fim, cumpre frisar que durante todo o espetáculo de informação e apresentação da morte, a morte, em si, não é mostrada. Como bem lembra Marialva Barbosa (2004, p. 01), “(...) a imagem do morto é substituída pela imagem do seu cortejo e do público que dele participa”. Ou seja, não são exibidas imagens do finado, mas apenas explorados a dor, a tristeza e todos os demais elementos relacionados à morte.

3 A obra de Guy Debord que tratou deste conceito é considerada vanguardista na análise crítica da sociedade de consumo. Nela, discorre sobre a influência do capitalismo na alteração dos hábitos e costumes sociais, bem como na produção dos bens culturais.

Rev.Cad. Comun, Santa Maria, v.21, n.1, art 6 p.130 de 145, jan/abr.2017 


\section{OS ESTUDOS CULTURAIS LATINO AMERICANOS}

Cabe pontuar que para análise da recepção caso Bernardo do Jornal Nacional, tomaremos como aporte teórico-metodológico a linha Latino-Americana dos Estudos Culturais. Os estudos latino americanos são uma vertente dos Estudos Culturais, sendo “(...) a corrente teórica mais influente junto às pesquisas de recepção (...) (BOAVENTURA; MARTINO, 2010, p. 03).

Consabido é que cada região possui hábitos e costumes que lhe são próprios, originando culturas diversificadas e únicas. Também variam no tempo e no espaço as relações de desigualdade no tocante à renda e ao acesso do ensino formal. Esse conjunto de fatores faz com que cada indivíduo ou grupo de indivíduos tenha uma percepção a respeito das informações que recebe, ou seja, a sua formação, a sua bagagem cultural está diretamente relacionada com as apropriações e entendimentos que produz das mensagens que recebe.

É a partir desta percepção que os estudos centrados na questão da cultura ganham força na América Latina e no Brasil, voltados para a percepção de que a cultura não existe na sua forma singular, pois se trata de uma realidade múltipla, na qual conhecimentos e valores sobrepõem-se e se entrelaçam, exigindo um olhar diferenciado para a sua compreensão. (TEMER, 2014, p. 151-152).

Infere-se, assim, que os estudos latino americanos visam trabalhar a recepção na perspectiva dos estudos culturais. Neste contexto, se destacam três autores principais: Jesús Martín-Barbero, Néstor García Canclini e Guillermo Orozco Gómez. Estes principais pesquisadores da linha de pesquisa latino-americana focam seu trabalho nos estudos de recepção, considerando que o receptor também produz sentidos, ou seja, a comunicação não ocorre de modo unilateral, passiva. Ainda, observa-se que eles enfatizam o estudo da recepção comunicacional nas mediações, não mais nos meios e, neste viés, os temas comunicação e cultura tornam-se indissociáveis. Diante desta forma diferente de pensar, foi unânime entre os pesquisadores a necessidade de alterar a metodologia de estudos, promovendo pesquisas qualitativas para aprofundar a discussão (BOAVENTURA; MARTINO, 2010).

Este trabalho está fundamentado no estudo das mediações proposto

Rev.Cad. Comun. Santa Maria, v.21, n.1, art 6, p.131 de 145, jan/abr.2017 
por Martín-Barbero. No que diz respeito ao conceito de mediação, não há um significado específico. Signates (1998) destaca que os pesquisadores dos estudos culturais não elaboraram uma definição técnica, apesar do frequente uso do termo "mediação" em seus trabalhos. "O próprio Martín-Barbero, em sua obra principal, De los medios a las mediaciones (1987), apesar de utilizá-lo no próprio título, não o define claramente, nem o historia. As contribuições nesse sentido são esparsas (...)" (SIGNATES, 1998, p. 37).

Para tanto, Martín-Barbero (2013) sugere três lugares para a mediação: a cotidianidade familiar, a temporalidade social e a competência cultural. No concernente a temporalidade social, ele afirma que a sociedade é regida por dois tipos de tempo: o de trabalho (que é produtivo e gera riqueza) e o livre (para o descanso, não gera lucros). A cotidianidade familiar diz respeito à família. São com estas pessoas, que lhe são próximas e convive diariamente, que o indivíduo busca amparo nas dificuldades e com quem compartilha as maiores alegrias. A competência cultural, ao seu turno, “(...) deve ser entendida como a bagagem cultural que o indivíduo carrega ao longo da vida, não somente focando na educação formal, mas englobando as experiências adquiridas ao longo da vida" (RIBEIRO; TUZZO, 2013, p. 04).

E uma das formas de proceder a este tipo de análise é através de estudos de recepção, em que é possível verificar “(...) o sentido que se produz a partir da experiência cotidiana com os meios”. (RONSINI, 2010, p. 02).

Diante desta proposta é que se faz o estudo neste trabalho: verificar como um grupo de advogados recepciona a morte, em especial no Caso Bernardo, nas transmissões feitas pelo Jornal Nacional; observar se apesar das diferentes bagagens culturais e sociais eles são capazes de questionar as notícias veiculadas e, em caso afirmativo, quais são esses questionamentos. Em suma, visa-se verificar os modos de apropriação das mensagens que recebem e a(s) resposta(s) emitida(s).

\section{A RECEPÇÃO DO JN NO CASO BERNARDO POR ADVOGADOS}

Como já salientado, este trabalho se propõe a fazer um estudo de recepção. Assim, ao elevar o receptor à categoria de produtor de sentidos, é indispensável a análise das manifestações dos espectadores sobre o que é veiculado pela mídia. Tais estudos, cumpre notar, ocorrem desde longa

Rev.Cad. Comun. Santa Maria, v.21, n.1, art 6, p.132 de 145, jan/abr.2017 
data. Conforme Robert White (1994, p.57): "a partir de meados dos anos 80 , tem ocorrido um movimento diferente, mais direcionado para as pesquisas que analisem os significados que as audiências efetivamente constroem sobre as mensagens da mídia".

De acordo com Martín-Barbero (2013), pesquisador cujas teorias embasam o presente trabalho, esta observação da audiência é denominada de "mediação". Para o autor, o foco de estudos deixa de ser os meios midiáticos e passa a ser o espectador, em virtude dos diversos entendimentos que ele pode criar sobre o fato noticiado.

Isto posto, para analisar a audiência que compõe este estudo, optou-se por aplicar um questionário e, após, fazer uma discussão de grupo a respeito da temática estudada.

O questionário aplicado tinha formato semiestruturado, composto por perguntas abertas e fechadas. $\mathrm{O}$ objetivo era que as respostas não ficassem engessadas, padronizadas, permitindo ao entrevistado expor seus pensamentos com mais clareza e liberdade (MANZINI, 1990/1991, p. 154).

As perguntas abrangeram tópicos socioeconômico-culturais, religião e morte, bem como hábitos informativos e opinião acerca das duas matérias selecionadas veiculadas pelo Jornal Nacional. O áudio do debate em grupo foi gravado com a finalidade de complementar a parte escrita.

Assim, o estudo de recepção foi implementado da seguinte maneira: foram escolhidos cinco advogados para formar o grupo. Primeiro, os integrantes responderam ao questionário. Na sequência, foram mostradas as duas notícias sobre o Caso Bernardo veiculadas pelo Jornal Nacional. Por último, formou-se o grupo para debates, visando promover e observar a troca de experiências.

O estudo prático se realizou no dia 23 de novembro de 2015. No grupo de advogados, composto por 3 mulheres e 2 homens, constatou-se que todos têm irmãos e que a educação formal de seus genitores varia entre ensino médio completo ou superior completo. Além disso, tal como os jornalistas, todos tem renda de, no mínimo 1 salário mínimo, possuindo televisão, computador e acesso à internet.

A respeito da cultura e do engajamento social, todos os entrevistados frequentam cinema, shows, bares/danceterias, sendo que apenas 1 entrevistado atua em alguma entidade ou associação.

A maioria (4/5) dos entrevistados disse que recebeu educação religiosa na infância. $O$ outro pesquisado deixou a pergunta em branco. Neste

Rev.Cad. Comun. Santa Maria, v.21, n.1, art 6, p.133 de 145, jan/abr.2017 
grupo, 3 se declararam como católicos, 1 como espírita e outro como apenas crente em Deus.

Ao serem questionados sobre a morte, $80 \%$ do grupo acredita em vida após a morte e $60 \%$ afirmaram ter medo da morte.

Deste grupo, $80 \%$ declarou assistir TV, dispensando, em média, mais de $2 \mathrm{~h}$ por dia para esta atividade. Cumpre frisar que uma das pesquisadas declarou não assistir televisão, não acompanhando telejornais ou o Jornal Nacional. Para esta entrevistada, os informativos televisivos "são muito manipulados, prefiro ler em meios alternativos".

Para manter-se informada, a audiência analisada declara que também acessa a internet. Indagados a respeito da influência que o telejornal exerce na opinião das pessoas, 3/5 dos integrantes entendem que pode haver influência na opinião pessoal e modo de vida, depende do caso.

Como já salientado, somente uma pesquisada disse que não assiste ao Jornal Nacional ou outro telejornal. Porém, dentre os que acompanham o principal informativo da Rede Globo, os argumentos mencionados foram:

- "Porque é um telejornal tradicional, que passa credibilidade e tem histórico de seriedade. Dá a sensação de que aborda todos os assuntos. Me sinto informado e completo";

- “Por ser um jornal sério e muito abrangente. Minha opinião é de que o jornalismo do JN necessita mais independência, ou seja, mais técnica e menos política";

- "O Jornal Nacional me passa uma ideia de parcialidade excessiva, não aborda os 2 lados da questão (na maioria das vezes, sequer menciona haver outro lado) ";

- "Minha opinião é de que se trata de um jornal parcial e tendencioso".

Como era de se esperar, em virtude da formação acadêmica deste grupo, a totalidade dos integrantes entende o significado do princípio da presunção da inocência bem como as etapas do procedimento de inquérito policial. Verifica-se, com isso, a mediação da competência cultural. Como

Rev.Cad. Comun. Santa Maria, v.21, n.1, art 6, p.134 de 145, jan/abr.2017 
pontua Ronsini et al (2009), essa mediação é aquela que engloba todas as referências culturais de um sujeito, desde a educação formal até as vivências do cotidiano.

Assim como os jornalistas, todos os advogados entrevistados entendem que as notícias mostradas induzem o telespectador ao entendimento que as pessoas indicadas como suspeitos são, em realidade, culpadas. Os motivos justificadores foram semelhantes àqueles apresentados pelos jornalistas: o formato da abordagem dos fatos, a ênfase em determinadas palavras, a ausência de manifestação da defesa e o destaque conferido para o pronunciamento da delegada.

A entrevistada 5 pontuou que:

Assisto pouca televisão por isso, acho que as coisas vêm muito prontas, para que tu formes essa opinião, é o que eles [mídia] querem. Acho que nesse caso está bem claro, em nenhum momento ninguém falou nada que pudesse deixar em dúvida a situação e, até que se prove o contrário, tem que existir alguma dúvida.

Desta manifestação da pesquisada é possível inferir, novamente, as mediações das competências culturais. Isso porque ela toma por base as rotinas jurídicas que lhe foram ensinadas na sua graduação em Direito, dando ênfase à necessidade de respeito ao princípio da presunção de inocência.

A entrevistada 4, por sua vez, disse:

Achei essa matéria, assim como minha opinião particular do Jornal Nacional, extremamente tendenciosa. Aparecem todas as provas, mas não aparece nenhum advogado de defesa colocando como se dá a defesa dos réus, suspeitos ou indiciados. Não se coloca que a fase é de inquérito ainda, que não se tornou processo judicial, que não houve denúncia, que o Ministério Público não se manifestou. Eles exploram isso, penso eu, porque a opinião popular clama por um culpado. (...). Acho muito complicado o papel da mídia como está colocado aí.

Tais perspectivas são do campo do direito e relativas à formação da entrevistada, ou seja, remetem à mediação da competência cultural, a qual diz respeito às vivências e educação formal de cada indivíduo.

Ao seu turno, a pesquisada 3 falou que "O público em geral não tem

Rev.Cad. Comun. Santa Maria, v.21, n.1, art 6, p.135 de 145, jan/abr.2017 
discernimento [para diferenciar os termos]". Ela ainda lembra que outros noticiários, às vezes, levam profissionais da área para comentar algum caso. Como exemplo, cita o caso da Boate Kiss, em que um especialista em segurança foi em um programa de TV e comentava sobre as possibilidades da ocorrência da tragédia, dando ao telespectador a oportunidade para refletir sobre o assunto. Diante disso, ela segue afirmando que: "Nessa reportagem mostrada, não há possibilidade de abrir o pensamento, ela já te dá as coisas prontas".

O pesquisado 1 reconhece, em parte o trabalho dos jornalistas. Porém, entende que:

Por mais que os jornalistas tenham se esforçado para usar os termos corretos, pelo menos uma vez transpareceu diferente. Que é quando, na $2^{a}$ reportagem, o William Bonner volta e diz que a polícia ainda está investigando qual foi a participação do irmão [de Edelvânia] no crime. Então, já se presume que teve participação do irmão no crime. Se tem dúvida de qual é a participação, mas não se ele participou ou não do crime.

Sobre a feitura de contraponto, de escutar o outro lado da história, o pesquisado 1 relata sobre pesquisa realizada por ele a respeito de reportagem da revista Isto É, envolvendo Cid Gomes, então Governador do Ceará. Ao analisar o processo judicial sobre este litígio, o entrevistado observou que a jornalista responsável, na época, enviou um email ao Governador, fazendo alguns questionamentos para que fosse feito o contraponto. Ocorre que dito email foi enviado ao suspeito na véspera da data de circulação da revista. E, então, o pesquisado pondera que:

Dizem que "O advogado foi procurado e não quis se manifestar", mas, na verdade, o sujeito nem teve tempo de pensar! Então eles [jornalistas] estão fazendo uma reportagem super elaborada sobre desvios de dinheiro (...), mas o email para permitir o contraponto foi enviado na véspera?!

A entrevistada 3 indica que esse tipo de conduta seduz o leitor, espectador. Isso porque "O público em geral busca o culpado, a explicação não importa".

Seguindo o debate, da mesma forma que se procedeu com os jornalistas, foi perguntado ao grupo se eles entendiam que havia uma construção maniqueísta, do bem $\mathrm{X}$ mal:

Rev.Cad. Comun. Santa Maria, v.21, n.1, art 6, p.136 de 145, jan/abr.2017 
Sem titubear, a entrevistada 4 respondeu: "Com certeza. Isso domina o inconsciente coletivo. Eles [a mídia] sabem disso e se utilizam disso com certeza".

A entrevistada 5, no entanto, apresentou entendimento diverso:

Eu não sei se é maniqueísta, acho que é muito uma questão de quem pode disseminar a opinião. É aquela coisa de poder, mesmo. Que cara que se quer dar para este evento neste momento? "Nós somos a Rede Globo e podemos dar a cara que a gente quiser pra isso"”.. Se é bom ou mal fica em segundo plano. "O que a gente [mídia] vai ganhar com isso? " Acho que é muito mais uma vantagem do que estar do lado do bem ou do mal.

A entrevistada 4 retoma seu pensamento e avalia:

Eu acho que tem o negócio do bem e do mal no sentido de que.... Também pelo poder..., mas eles se utilizam disso para mostrar que estão buscando o culpado, muito mais do que a polícia, por exemplo. "Nós estamos atrás de apurar os fatos", tipo herói e vilão, o mocinho e o bandido. Se alocam como a face do bem. Tem uma coisa de justiça.

Uma visão mais crítica é proferida pelo pesquisado 1. Ele entende que embora a reportagem tenha usados os termos (suspeito, acusado, indiciado), o jornalista pode não saber o significado de tais termos, bem como não saber as características e os procedimentos do inquérito. $\mathrm{E}$, com isso, o jornalista acaba por conferir “(...) uma legitimidade muito grande ao que a delegada falou". O entrevistado ainda destaca que "O tempo do jornalismo é diferente do tempo do processo e da justiça, e tem que ser [assim]. Existe uma exigência que a sociedade faz no jornalismo pela celeridade, pela rapidez [que não se coaduna com a velocidade da justiça]".

A entrevistada 3, seguindo esta lógica, aponta que não se pode confundir o imediatismo com a espetacularização da notícia, pois são conceitos diferentes. Em sua opinião, a mídia usa determinados formatos e abordagens porque é o que o espectador quer assistir e, portanto, aquilo que vai vender e dar audiência.

Nessa linha de pensamento, o imediatismo significaria informar o fato tão logo ele ocorra, para que a sociedade se mantenha atualizada. Por sua vez, a espetacularização mencionada pela pesquisada se insere na lição de Guy Debord (1997) sobre o que denominou de "Sociedade do Espetá-

Rev.Cad. Comun. Santa Maria, v.21, n.1, art 6, p.137 de 145, jan/abr.2017 
culo". Para o autor, as notícias se transformaram em mercadorias e o que mais importa é a venda, a obtenção de lucro. Ou seja: pouco importa a qualidade da notícia, admitindo-se, inclusive, a manipulação de dados para vendê-la.

A entrevistada ainda afirma que:

Para mostrar a humanidade do evento, o jornalismo precisa mostrar a mãe chorando porque perdeu o filho. E aí tu vês que o público que assiste a esses telejornais não é um público mais intelectual, que tenha mais estudo. E aí acaba por influenciar mais por isso.

A partir da opinião da entrevistada, podemos resgatar a ideia sobre a morte já citada anteriormente de que a mídia é utilizada como um palco para o extravasamento da morte. Ou seja, cenas que não tem mais espaço no cotidiano das sociedades ocidentais atuais ganham visibilidade nos telejornais.

Seguindo a ideia de espetacularização, a entrevistada 5 cita como exemplo a tragédia com o avião fokker 100 da TAM, em que os repórteres perguntavam aos familiares como eles estavam se sentindo, enquanto aguardavam notícias sobre a identificação dos corpos.

As entrevistadas 3 e 4 , no tocante a questão sobre não mostrar o outro lado dos fatos e ainda na ideia de espetacularização, lembram do caso Richthofen em quem, num primeiro momento, "castigaram" e culparam a acusada Suzanne. Porém, decorrido algum tempo, fizeram matéria sobre a rotina dela na cadeia, seus relacionamentos. Uma reportagem diferente, mas, de novo, um espetáculo, um artifício para manter o caso vivo e vender.

Após todas essas manifestações, o entrevistado 2 resolveu opinar e disse:

Vou muito além do que é o espetáculo da notícia. A comunicação, querendo ou não, é o $4^{\circ}$ poder. É mais do que juiz, do que promotor, do que qualquer coisa. Quem faz direito acaba sendo massacrado, porque esse $4^{\circ}$ poder vem pra te detonar, te desestimular. Por mais que esse advogado [de defesa] tenha sido contatado e ele queira fazer alguma coisa, a mídia vai detonar ele. Então ele já nem vai. A matéria do Bernardo, não é do Bernardo. É de uma criança, de uma madrasta, de uma relação familiar. Essa culpa do Bernardo vai muito além. Eu vejo que o juiz é 
muito mais culpado do que a madrasta e o pai, porque a criança foi lá pedir ajuda e o juiz não fez nada.

Tal entrevistado ainda pondera que a comunicação, na atualidade, tirou o foco da notícia, do fato e o colocou no lucro, uma vez que o objetivo é vender, obter lucro. E destaca que para reforçar a tese apresentada pelo telejornal, para que o informativo venda a sua ideia, a própria edição, em uma das reportagens, mostra as pessoas indo para a frente da casa de Bernardo, protestar contra os acusados. E, com isso, ele concorda com o que foi antes relatado pelos demais participantes, de que o Jornal Nacional já vem com um pacote pronto. A entrevistada 4 complementou: "Tu vives numa lógica mercadológica, ainda mais na comunicação. Tem que vender". Aqui, novamente se insere o pensamento de Debord (1997), que pode ser relacionado com o ensinamento de Rodrigues (1983), concluindo-se que todo espetáculo é feito para vender, inclusive o da morte.

Sobre os termos técnicos, o pesquisado 2 ponderou que: "Antigamente a comunicação era trabalhada, elaborada. Hoje as pessoas mandam email na véspera, como o colega falou [referindo-se ao caso Isto É/Cid Gomes]".

A entrevistada 2 complementa o exposto dizendo que "Por essas notícias sem aprofundamento], tudo mundo acha que sabe. Qualquer pessoa que perguntar na rua o que acha sobre o caso Bernardo, ela vai te dizer, as pessoas têm opinião".

Então, o participante 2 exemplifica essa falta de aprofundamento mencionando uma situação que enfrentou no seu dia-a-dia como advogado:

Eu tive um caso na Justiça Federal que prenderam um cara, já avisaram a família e, quando chegamos na Polícia Federal, já estava RBS, "circo" todo armado. E aí tu pensas: "Peraí, tá mal! Primeiro chama a RBS? " A sorte é que era a [juíza] Dra. Dulce (...). Cheguei lá e disse: "Ó Doutora, como assim? Se botarem a cara dele [cliente] lá na mídia, vou responsabilizar a senhora, também. Porque isso é efeito cascata: o delegado mandou chamar a RBS, a senhora está autorizando a RBS filmar a cara do meu cliente e eu nem conversei com ele, ainda! Nem me deixaram conversar com ele!". Aí começaram com uma desculpa lá, para esperar um pouquinho que estavam terminando alguma coisa. Então a Dra. Dulce se deu conta que eu tinha razão, recém prenderam o cara, não começaram nem a fazer o flagrante. Aí ela ligou pessoalmente para o delegado, que "surtou". Resultado: acabou não saindo a imagem dele, foi uma notícia um pouco

Rev.Cad. Comun. Santa Maria, v.21, n.1, art 6, p.139 de 145, jan/abr.2017 
mais séria, no sentido de informar. Falta isso. Nós que estamos no direito temos que batalhar por isso. Senão, vai continuar [essa realidade de espetáculo e pouca profundidade].

Em tempo, a pesquisada 4 destaca o recente caso dos ataques terroristas na França, sobre os quais a mídia só mostra o lado das vítimas francesas, não mostra a história e o que está acontecendo no oriente médio. "O foco, o interesse, é identificar o culpado pelos ataques", afirma. A entrevistada 2 concorda com a afirmação da colega: "A TV não mostrou os bombardeios ao estado islâmico, em que muitos inocentes morreram, mídia não fez este contraponto".

No entanto, a respeito dos ataques à França, a entrevistada 4 assevera que não é só a Globo que faz isso. Ela acredita que é uma lógica mercadológica que as grandes emissoras obedecem.

Nesse contexto, surge a preocupação da entrevistada 2 a respeito da perda da qualidade das notícias. "As pessoas querem abrir o celular e ter uma notícia nova. E os veículos de comunicação ficam naquela 'se eu não publicar, o colega vai publicar e eu vou perder de vender minha notícia”". E então, conclui ela, que devido à pressa do jornalista, muitas notícias são divulgadas sem o devido aprofundamento.

Importante salientar que, muitas vezes, essa falta de aprofundamento pode ser atribuída às próprias rotinas de coberturas televisivas. Um argumento para tanto pode ser a escassa bibliografia específica sobre como fazer coberturas jornalísticas. São poucas as fontes que o jornalista tem para consultar sobre como proceder e o que abordar durante a cobertura. Outra explicação pode ser encontrada no tempo que o jornalista tem para sua matéria, seja o tempo de elaboração (“deadline”), seja o tamanho do espaço que the foi conferido para produzir sua reportagem.

Diante de tudo o que foi analisado, tanto dos questionários quanto do que foi colhido durante o debate em grupo, fica evidente a tese adotada por Martín-Barbero. Isso porque os telespectadores produziram sentidos (ao concordar ou discordar do colega) a partir de sua bagagem cultural, de suas vivências, experiências e, até mesmo, do seu trabalho. Também fizeram relações com casos semelhantes ao abordado na presente pesquisa, comparando a forma com que foram divulgados pela mídia. 


\section{CONSIDERAÇÕES FINAIS}

A cobertura jornalística que serviu como alicerce ao presente trabaIho, o Caso Bernardo, abordou assuntos como a morte e a cobertura da mesma no telejornalismo. A morte é um assunto obscuro. As explicações, as formas de entendimento e enfrentamento se modificaram não apenas ao longo da história, mas também variam conforme a cultura e a religião. Atualmente, a morte ainda é negada, eis que impera a necessidade de aproveitar a vida ao máximo, reduzindo-se cada vez mais os rituais de luto.

O medo do desconhecido faz com que a finitude humana seja um dos temas mais delicados e controvertidos da atualidade (SIMMEL, 1998). Ao mesmo tempo em que esse desconhecimento causa preocupação e temor às pessoas, ele serve de elemento fundamental para o homem reconhecer a sua finitude. É justamente por ter ciência da sua mortalidade que o indivíduo valoriza a vida e procura aproveitar ao máximo as oportunidades que lhe são apresentadas.

No entanto, quando a morte é midiatizada, ou seja, transformada em notícia, ocorre justamente o inverso. Todas as condutas que são negadas passam a ser permitidas, desejadas e exploradas. Movidas pela necessidade capitalista constante de lucro e audiência, as emissoras de televisão exploram ao máximo os sentimentos e as emoções gerados pela situação de morte. Com isso, a morte atinge um grande número de pessoas, inclusive aquelas que negam a morte. Cumpre lembrar que essa forma espetacularizada de reportar a morte humana vai ao encontro da tese lançada por Guy Debord (1997) de "Sociedade do Espetáculo" e produz, com certa frequência, um jornalismo tendencioso. Nas notícias elaboradas pelo Jornal Nacional a respeito do Caso Bernardo não foi diferente, como restou comprovado pelo estudo de recepção realizado.

Foi unânime entre os advogados o entendimento de que as reportagens analisadas impõem ao telespectador uma conclusão definitiva de que os suspeitos são, de fato, culpados. Em que pese as notícias selecionadas tratarem da fase de investigação e inquérito policial, etapa preparatória do processo e ainda distante da fase de julgamento.

Outro fato interessante foi que o grupo de advogados abordou, espontaneamente, a situação da espetacularização das notícias ao desenvolver a ideia de falta de aprofundamento das reportagens. Ou seja, mesmo aqueles que não têm conhecimento das teorias jornalísticas sobre essa

Rev.Cad. Comun. Santa Maria, v.21, n.1, art 6, p.141 de 145, jan/abr.2017 
temática já observaram esse tipo de abordagem e entendem que isso é inadequado.

O grupo de jornalistas partilhou da mesma opinião, de que a abordagem feita pela mídia não está adequada. No entanto, nem os advogados nem os jornalistas chegaram a um acordo a respeito de quem seria esta culpa: se do próprio jornalista ou se do sistema social vigente, que sofre grande influência do capitalismo e não investe em educação formal de qualidade.

Cumpre lembrar que este artigo é um recorte de uma pesquisa que abordou advogados e jornalistas, salientando que os últimos também identificaram a espetacularização da morte nas reportagens mostradas.

O grupo de advogados também observou que esta forma de exploração dos sentimentos e da dor dos envolvidos é repetida em todas as coberturas que abordam a finitude humana, não se restringindo ao Caso Bernardo. Inclusive, citam outros casos semelhantes para justificar sua opinião. Tal entendimento se justifica porque não se verificou, em nenhum momento, reportagens de maior profundidade e retorno para a sociedade a partir do Caso Bernardo. A imprensa, por exemplo, poderia ter feito matérias mostrando as falhas na rede de proteção à criança e ao adolescente, despertando a sociedade para a necessidade de exigir a implementação de políticas públicas eficientes, mas se manteve silente a esse respeito.

É possível inferir, portanto, a presença da bagagem cultural e das realidades de cada entrevistado ao se manifestarem sobre o Caso Bernardo, ou seja, realizando as mediações com os produtos midiáticos, exatamente como propôs Martín-Barbero (2013).

A discussão sobre este assunto é igualmente interessante para pesquisa tendo em vista as leis vigentes no Brasil. Vivemos em um Estado Democrático de Direito que tem como uma das garantias constitucionais o princípio da presunção da inocência. De acordo com este preceito, um indivíduo só pode ser considerado culpado quando a sentença condenatória transitar em julgado, ou seja, quando não houver mais possibilidade de recurso. A finalidade desta regra é evitar julgamentos equivocados e manter o respeito à dignidade da pessoa humana.

No entanto, diante de todo o exposto, infelizmente, não é o que tem se verificado com base no que a imprensa noticia. Considerando a importância do jornalismo na vida social, bem como a influência da comunicação na opinião e na vida do telespectador, resta cristalina a necessidade de se

Rev.Cad. Comun. Santa Maria, v.21, n.1, art 6, p.142 de 145, jan/abr.2017 
alterar alguns formatos jornalísticos, para que seja entregue ao espectador uma notícia correta, sem suposições inadequadas.

\section{REFERÊNCIAS}

ARIÈS, Philippe. História da morte no ocidente. Rio de Janeiro: Ediouro, 2003.

BARBOSA, Marialva Carlos. A morte imaginada. In: Encontro anual da associação nacional dos programas de pós-graduação em comunicação, 2004, São Bernardo do Campo. Anais. São Bernardo: Compós, 2004.

BARP, Luiz Fernando Greiner. A morte de Amy Winehouse como acontecimento no Fantástico e no Jornal Nacional. 2012. 25f. Trabalho de Conclusão de Curso. Curso de Comunicação Social - Jornalismo, Universidade Federal de Santa Maria, Santa Maria, 2012. Disponível em: <http://decom.cesnors.ufsm.br/tcc/files/2013/06/luiz.pdf>, acesso em 29 de outubro de 2014.

BOAVENTURA, Katrine Tokarski; MARTINO, Luiz Claudio. "Estudos culturais latino-americanos: convergências, divergências e críticas". Intexto, Porto Alegre, v. 1, n. 22, p. 3-19, jan./jun., 2010.

COUTINHO, Iluska Maria da Silva. Programa e público brasileiros: a trajetória do Jornal Nacional nas vozes de seus personagens. In: VI CONGRESSO NACIONAL DE HISTÓRIA DA MÍDIA, 2008, Niterói. Anais. Niterói, 2008.

DEBORD, Guy. A Sociedade do espetáculo. Rio de Janeiro: Contraponto, 1997.

ERBOLATO, Mário L. Técnicas de codificação em jornalismo. São Paulo: Ática, 2008.

GOMES, Itania Maria Mota. "O Jornal Nacional e as estratégias de sobrevivência econômica e política da Globo no contexto da Ditadura Militar". Revista FAMECOS, Porto Alegre, v. 17, p. 5-14, 2010.

LISITA, Enzo de. A morte servida na hora do almoço: O papel da televisão na banalização da morte e a desvalorização da vida. In: III ENCONTRO DE PESQUISA EM COMUNICAÇÃO E CIDADANIA, 2009, Goiânia. Anais. 2009, p. 1-11.

MAIA, Wander Veroni. Edição no Jornal Nacional e Jornal da Record: Uma análise

Rev.Cad. Comun. Santa Maria, v.21, n.1, art 6, p.143 de 145, jan/abr.2017 
CADERNOS DE COMUNICAÇÃO

UNIVERSIDADE FEDERAL DE SANTA MARIA

comparativa a partir dos critérios de noticiabilidade dos telejornais de rede. 2007.

<http://www.bocc.ubi.pt/pag/maia-wander-edicao-jornal-nacional-jornal-record.pdf>. Acesso em 17 de outubro de 2015.

MAIA, Alice Silva Corrêa. O telejornalismo no Brasil na atualidade: em busca do telespectador. In: XVI CONGRESSO DE CIÊNCIAS DA COMUNICAÇÃO NA REGIÃO SUDESTE, 2011, São Paulo. Anais. São Paulo: Intercom Sudeste, 2011.

MANZINI, Eduardo J. “A entrevista na pesquisa social”. Didática. São Paulo, v. 26/27, p. 149-158, 1990/1991.

MARTÍN-BARBERO, Jesús. Dos Meios às Mediações: Comunicação, cultura e hegemonia. Rio de Janeiro: UFRJ, 2013.

Memória Globo. Jornal nacional - A Notícia faz história. Rio de Janeiro: Jorge Zahar Editor, 2004.

NEGRINI, Michele. A morte em horário nobre: a espetacularização da notícia no telejornalismo brasileiro. 2010. 248 f. Tese - PUC RS, Porto Alegre, 2010.

OROZCO GÓMEZ, Guillermo. La Perspectiva Cualitativa. In: . La investigación en

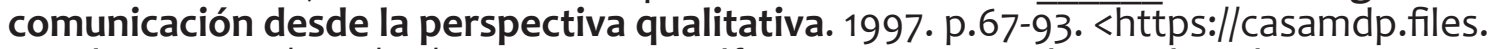
wordpress.com/2013/08/orozco-cap-iv.pdf>. Acesso em 28 de outubro de 2015.

PATERNOSTRO, Vera Íris. O texto na TV. Rio de Janeiro: Campus, 1999.

REDÜ, Natália Sheikha; NEGRINI, Michele. A Morte Como Laço Social: Reflexões Sobre A Cobertura De Zero Hora Ao Aniversário Da Morte De Bernardo Boldrini. In: XXXVIII Congresso brasileiro de ciências da comunicação, 2015, Rio de Janeiro. Anais. Rio de Janeiro: Intercom 2015

RIBEIRO, Luiza Carla; TUZZO, Simone Antoniaci. Jesus Martín Barbero e seus estudos de mediação na telenovela. Revista Comunicação \& Informação, Goiás, v. 16, n. 2, p. 39-49, jul./dez. 2013.

RODRIGUES, José Carlos. Tabu da morte. Edições Achiamé Ltda: Rio de Janeiro, 1983.

RONSINI, Veneza Mayora. A perspectiva das mediações de Jesús Martín-Barbero (ou como sujar as mãos na cozinha da pesquisa empírica de recepção). In: XIX Congresso nacional dos programas de pós-graduação em comunicação, 2010, Rio de Janeiro.

Anais. Rio de Janeiro: Compós, 2010.

SIGNATES, Luiz. Estudo sobre o conceito de mediação. Novos Olhares, São Paulo, n. 2,

Rev.Cad. Comun. Santa Maria, v.21, n.1, art 6, p.144 de 145, jan/abr.2017 
p. 37-49, $2^{\circ}$ Semestre de 1998.

SIMMEL, George. A metafísica da morte. Política \& Trabalho: Revista de Ciências Sociais do PPGS-UFPB, João Pessoa, ano 14, n. 14, p.177-182, set. 1998. Tradução de: Simone Carneiro Maldonado. Disponível em: <http://www.oocities.org/collegepark/ library/8429/14-simmel-1.html\#EndNote1>, acesso em 09 de maio de 2015.

TEMER, Ana Carolina Rocha Pessôa. A Tradição dos Estudos Culturais na Perspectiva das Contribuições Latino-americanas. Novos Olhares, São Paulo, Vol.3, n. 2, p. 150-159, $2^{\circ}$ Semestre de 2014.

YIN, Robert K. Estudo de Caso: Planejamento e Métodos. 5.ed. Porto Alegre: Bookman, 2015.

WHITE, Robert A. Recepção: a abordagem dos estudos culturais. Comunicação \& Educação, São Paulo, v. 4, n.12, p.57-76, mai./ago. 1998.

\section{Natalia Redü}

Graduada em Jornalismo pela Universidade Federal de Pelotas.

E-mail: nataliaredu@gmail.com

\section{Michele Negrini}

Doutora em Comunicação pela Pontifícia Universidade Católica do Rio Grande do Sul, mestre em Comunicação e Informação pela Universidade Federal do Rio Grande do Sul. Docente da Universidade Federal de Pelotas.

E-mail: mmnegrini@yahoo.com.br

RECEBIDO EM: 04/04/2016

ACEITO PARA PUBLICAÇÃO: 03/06/2016 